\title{
MEASURING THE RELATIONSHIP BETWEEN THE THEORETICAL KNOWLEDGE GIVEN IN ACCOUNTING EDUCATION AND THE ACCOUNTING SECTOR PRACTICES: EVIDENCE FROM AYDIN
}

\author{
Çă̆rı KÖROĞLU1 \\ Yusuf KADERLİ2 \\ Yusuf ZEYTUN ${ }^{3}$
}

\begin{abstract}
The process of globalization led to essential developments both in national and international trade. In parallel with these developments, firms need accounting as a core element to present their business activities correctly, credibly, comparably and understandably. In this sense, accounting became an important element for all firms. To meet the need for qualified work force in the area of accounting, a good number of associate degree and undergraduate degree programs are established in Turkey. However as in all sectors, the differences between theoretical knowledge gathered through education and sectoral practices present a problem in accounting sector as well.

The aim of this study is to identify if there is a significant difference between the theoretical knowledge in associate degree and undergraduate degree accounting education and the accounting sector practices. For this purpose, an interview study is implemented to independent accountants registered to Aydin Chamber of Certified Public Accountants with a simple random sampling method in order to reveal the relationship between theoretical knowledge and implementation of sector.
\end{abstract}

Keywords: Accounting, Accounting Education, Accountant.

\footnotetext{
${ }^{1}$ Yrd. Doç. Dr., Adnan Menderes Üniversitesi, İktisadi ve İdari Bilimler Fakültesi, İşletme Bölümü, cagrikoroglu@hotmail.com.

2Doç. Dr., Adnan Menderes Üniversitesi, İktisadi ve İdari Bilimler Fakültesi, İşletme Bölümü, ykaderli@yahoo.com.

${ }^{3}$ Araș. Gör., Adnan Menderes Üniversitesi, İktisadi ve İdari Bilimler Fakültesi, İşletme Bölümü, yusufzzeytun@gmail.com.
} 


\title{
MUHASEBE EĞITTIMINDE VERILEN TEORÍK BÍLGİ ÍLE MUHASEBE SEKTÖR UYGULAMASI ARASINDAKİ İLIŞKININ ÖLÇÜLMESİ: AYDIN İLİ ÖRNEĞ́̇
}

\begin{abstract}
ÖZ
Günümüzde küreselleşmeyle birlikte gerek ulusal gerekse de uluslararası ticarette önemli gelişmeler yaşanmaktadır. Bu gelişmelere paralel olarak, işletmeler yapmış oldukları ticari faaliyetleri, ilgili kişi ve kurumlara doğru, güvenilir, karşılaştırılabilir ve anlaşılabilir biçimde sunması için muhasebeye ihtiyaç duyacaktır. Bu anlamda muhasebe, bütün işletmelerin göz önünde bulundurması gereken önemli bir unsur olmuştur. Muhasebenin bu derece önemli bir yapıya sahip olmasl, muhasebe faaliyetlerini yerine getirecek kişilere olan ihtiyacı arttırmış ve bu ihtiyacın karşılanabilmesi için Türkiye'de birçok lisans ve önlisans düzeyinde muhasebecilik mesleğine yönelik bölümler açılmıştır. Ancak, her sektörde olduğu gibi muhasebecilik sektöründe de eğitim döneminde verilen teorik bilgiler ile sektör uygulamaları arasında farklılıkların olması önemli bir sorun teşkil etmektedir.

$\mathrm{Bu}$ çalışmanın amacl, muhasebe meslek mensuplarının lisans veya önlisans düzeyinde muhasebe alanında almış oldukları eğitim ile sektör uygulamaları arasında belirli bir farklılığın olup olmadığının tespit edilmesidir. Bu amaçla, Aydın Serbest Muhasebeciler ve Mali Müşavirler Odası (SMMMO)'na kayıtlı mali müşavirlere basit tesadüfi örnekleme yoluyla mülakat yöntemi yapılıp teorik bilgi ile sektör uygulaması arasındaki ilişki ortaya konulmaya çalışılmıştır.
\end{abstract}

Anahtar Kelimeler: Muhasebe, Muhasebe Eğitimi, Muhasebe Meslek Mensubu.

\section{Introduction}

Recently, there has been various changes in trade in Turkey like in other countries in the world. In parallel with this changes, firms are now operating in more than one location. Firms need accounting to present their business transactions completely to related parties. Thus, accounting is a core element that every firm has to implement and take into consideration. The high importance of accounting and the increasing need of accounting knowledge in international economics caused new employment areas in accounting and also the number of people employed in existing areas become insufficient (Yayla and Cengiz, 2005: 148). Therefore, many associate degree and undergraduate degree programs in Turkey provide training for accountancy and present sufficient equipment to efficient use of information related with profession. But, as in other sectors, the theoretical knowledge given in education has some differences from the practices in accounting sector. These differences cause an important problem. The problem is that individuals question which of the information they learnt is more useful. These 
differences also cause some adaption problems in early years of work lives of newly graduated people.

The aim of this study is to identify if there is a significant difference between the theoretical knowledge in associate degree and undergraduate degree accounting education and the accounting sector practices. For this purpose, first of all the accounting education concept is approached. Following this, the accounting profession is described and the difference between accounting education and accounting profession is explained theoretically. In the final part of the study, the results of interview study, which is implemented to independent accountants working in Aydın in order to identify if there is a significant difference between the theoretical knowledge in accounting education and the accounting sector practices, is commented.

\section{Accounting Education}

Under current economic conditions that makes competitive advantage an important factor, firms need accounting in order to collect, report and control information that is needed to make profit, prevent problems and provide sustainability (Hyvönen, 2003: 155). In the most general sense, accounting is detecting, collecting, processing, crosschecking and reporting information useful in management decisions and informing how to use the reported information for decision making procedure and finally informing related parties regarding the application of these information with the help of developing information technologies (Durak, 2009: 5).

As it is seen from the definition of accounting, the expansion of business connection also expanded the dimension of accounting and obligated accounting to provide required information to persons and institutions. The realization of this obligation of accounting depends on giving correct and complete education to responsible people of accounting. Thus, accounting education is the core element for accounting to fulfil its responsibilities. In the most general sense, accounting education can be defined as informing students and improving their skills regarding the functions of accounting, which are detecting, collecting, processing, crosschecking and reporting and using information required for management decision processes (Dursun, 2006: 53). As it is seen from definition, it is an education to provide the person required knowledge, skills and behaviors (Paksoy et al, 2005: 76).

Taking accounting education as a system, we can divide it into three subsystems. These are financial accounting, managerial accounting and cost accounting (Murthy and Wiggins, 1999: 3). All over the world and in Turkey, education institutions, the courses as 
part of accounting education, are evaluated within the frame of these three subsystems. In other words, these three accounting types in accounting education system are the courses that education institutions must teach. As an evidence, when we look at European Union member countries education system, we see that financial accounting, cost accounting and managerial accounting are compulsory courses in business administration departments (Karapinar, 2001: 218). Concordantly, corporate accounting, construction accounting, responsibility accounting and the like are given as elective courses.

The accounting education in Turkey shows that, even though the number, level, content and quality of accounting courses show differences from one university to other, accounting related courses have a big part in business administration curriculum. For instance, accounting courses constitutes the 17 percent of all courses instructed in Adnan Menderes University Business Administration Department. Although no consensus exists in Turkey regarding the business administration department's accounting programs, the accounting courses instructed in business administration departments are as follows; General Accounting, Corporate Accounting, Cost Accounting, Managerial Accounting, Computerized Accounting, Financial Statement Analysis, Advanced Accounting and Accounting Control.

\section{The Relationship between Accounting Profession and Accounting Education}

With the changes occurred in activity areas of firms, the accounting information, known as the language of the firm, became much more important for the firms. The owners and shareholders of a firm are not the only ones directly related with the activities and results of the firm. Apart from these, institutions, individuals, banks, investment firms and some public institutions are also related with the activities and results of the firm as a result of having commercial, financial and economic relationship with the firm. Stakeholders require reliable information in this respect. The resource of information for the activities and results of a firm are the accounting records, documents and financial statements prepared based on the records and documents (Şengel, 2011: 4).

The information gathered from financial statements must be correct, clear, understandable and reliable. Only this will protect stakeholders and provide benefit to them. Because financial statements that are defrauding, containing mistakes and missing information would be far from truth for the stakeholders (Okay, 2011: 
110). In this respect, accounting profession takes an important task on carrying out economic and financial activities of firms.

In the most general sense, accounting profession is a field of profession that continuously produces knowledge in parallel with the technologic developments and changes in regulations, provides knowledge to interest groups, gives decisions with professional judgment and has mainly application activities (Dinç and Kaya, 2006: 141). In accounting profession sector, as in all areas of profession, competition plays a great role and thus the effort to raise qualified individuals becomes increasingly important (Yayla and Cengiz, 2005: 149). Therefore, there is a strong relationship between accounting profession and accounting education. The subsystems of the abovementioned system form the basis of this relationship. Because, these subsystems determine the relationship between education and practices regarding the sector that the firm operates in.

To illustrate;

- If member of accounting profession has sufficient knowledge regarding financial accounting, he/she will have the opportunity to provide required information to shareholders, investors, creditors and government agencies with the help of various financial statements (Hansen et al, 2007: 4).

- If member of accounting profession has sufficient knowledge regarding managerial accounting, he/she would contribute to the transparency of details of activities of the firm by preparing various reports. He/she would also help to form an organizational control mechanism that eases control by increasing the performance in the areas where those details are used (Chia, 1995: 812). In addition, the person having sufficient knowledge in this accounting, would contribute to taking planning, controlling and special management decisions of the firm (Hansen et al., 2007: 4).

- If member of accounting profession has sufficient knowledge regarding cost accounting, he/she would, generally in manufacturing firms, not only detect the formation of costs of produced goods and services but also form the relation between these costs and decisions given by managers.

In fact, the examples given above, regarding the use of accounting knowledge in appropriate areas and sectors, reveal the relationship between accounting education and accounting profession. Accounting education system has a direct effect on the reliable and efficient practice of accounting profession.

\section{Material and Method}

Field study is implemented on independent accountants and financial advisors (IAFAs) in Aydin province. Face-to-face interview 
method is used in this study. This method is applied in February 2015 and 20 people are interviewed in total. There are 20 questions in the interview, which are detailed in the findings and discussion part.

4 questions directed are demographic. The other questions start with the subject of accounting education and continue with the importance of accounting education, the contributions of it to the sector and the ideas of IAFAs regarding how a better accounting education can be possible.

\section{Findings and Discussion}

The questions directed to IAFAs in the interview and the comments of the responses they gave were placed under this heading.

\section{Demographical Questions}

The questions in this part concern gender, age, professional experience and whether there is a member of the profession in the family. Of the IAFAs attended the study, 18 were males and 2 were females. We can infer that females preferred this profession less than males did. Age range of the interviewees is between 30 and 58. The answer "no" was more preferred among the answers they gave to the question as to whether there is an accountant in your family, which was a demographical question. However, elderly group of IAFAs stated that they wished to transfer their experiences to their children by expressing that their sons or daughters were studying now, and that they wanted to make them accountants.

The first four questions concern gender, age, professional experience and whether there is a member of a profession in the family. Other Questions Directed To Respondents And The Answers Given Are Summarized Below

Is the reason why you are in the accounting sector due to the circumstances that pushed you to the sector or due to the circumstances that attracted you?

of the 20 IAFAs responded to that question, 6 of them stated that they are in the profession due to the circumstances that pushed them, and 14 stated that they are in the profession due to the circumstances that attracted them. It has been observed that the participants who responded in favor of the pushing circumstances were composed of elder participants. As a result of this, it can be stated that the profession IAFA becomes more and more attractive day by day.

To what extent were the accounting courses that you took in your educational life effective in your preference of accounting profession?

It has been observed that the courses taken in the educational life were not in general bearing much importance in choosing such a career, but all the IAFAs attended the interview emphasized the fact

294 | Celal Bayar Üniversitesi Sosyal Bilimler Dergisi - Cilt: 13, Sayı: 2, Haziran 2015 
that the accounting courses they took were mainly effective in choosing this profession.

To what extent was the accounting education you took sufficient for you to carry out the accounting profession?

While the elderly people in the accounting sector responded that question as very effective, the younger ones responded it as not that important or not important. There are some results that can be inferred from here. One of them is that the accounting education was much more effective in the past when compared to today, and the education of accounting was previously taken from the doyens of the profession given the number of the universities in our country, and then it has become a general education. It is clear that competition will rise with the increase in the number of universities in Turkiye. Today individuals have easier access to internet and information and they are more educated than before. Thus, we can say that information is everywhere and information is in the hand of who reaches to it.

When you compare the accounting education you received with the accounting sector in real life, to what extent does the knowledge you acquired shed light to the accounting sector in the real life?

The general answer given to that question is that the accounting education does not shed much light to real life experience. The general opinion is that for those who will work as accountants should take both theoretical and practical education simultaneously.

If you had graduated from a better school, do you think that you would be way more effective and more profitable than your current situation?

While a small portion of the IAFAs had the idea that those who could speak a foreign language could follow the international developments with the answer "yes", the majority answered this question as "no", and added a few items to their answers:

- No but if I had taken my education in a private university rather than a state university, I would have been more active in the sector and I would have made more money,

- No, the most critical factor for the person to be more active and to make more money is the tendency towards accounting, and the attempt to learn individually, and being open to progress.

- No, because the taxpayers pay importance not to our knowledge and equipment but to how we can make them pay less tax, 
- No, because the most important factor to be more active and profitable in our profession is the environment of a person.

If you have any training in any of the accounting department of a business or in accounting sector, to what extent did this training play role in your preference of accounting profession?

The majority of the participants stated that they had training before starting the accounting profession, and that the training was one of the most important factors playing role in their preference of this profession.

To what extent is your educational background effective in solving a problem when you meet one in accounting profession?

IAFAs gave three different answers to this question and the number of the answers was equal. While a part of them stated that it was effective, the other part stated that it was partially effective. Those who answered "no" expressed that the accounting profession had multiple dimensions, and that they could overcome the problems only after gaining experience by referring to the bank, tax and legal dimensions of the profession. In addition, those who answered as "no" stated that there were various profession groups in the sector, and that there are various problems in those sectors, and that they overcame the problems by branching out in the profession.

How much updated do you think the accounting education in our country is?

The minority of the IAFAs responded this question as not updated. Those who defended that it was up to date commented on the topic by measuring the accounting education of both themselves and the trainees working in their offices. In addition, they stated that IAFAs were constantly educated by the seminars held by chambers of accounting profession, and that the accounting sector had constantly been updated.

To what extent are the financial accounting courses you took as to decision making effective in the accounting office you work in?

IAFAs dominantly answered this question in a way to state that it was important, and it was found out that the idea that those who does not know financial accounting cannot carry out the profession was prevalent.

To what extent is the management accounting course you took effective in the management mechanism of the businesses in terms of both individually and organizationally?

A minor portion of the IAFAs answering the question stated that they could not take this course. Those who took this course expressed

296 | Celal Bayar Üniversitesi Sosyal Bilimler Dergisi - Cilt: 13, Sayı: 2, Haziran 2015 
that taxpayers should be on institutional level in order for the management accounting to be used actively in decision making.

Is the cost accounting course you took sufficient in terms of cost calculation and right decision making in production businesses and businesses producing goods and service?

The IAFAs who answered this question as "yes, it is effective" defended the idea that it was effective in terms of big businesses using cost accounting while they stated that cost accounting had a cost in small businesses; thus, there was no real use of cost accounting in Turkey. Those who answered as "no, it was not effective" stated that the cost accounting taught formally in the classes did not correspond to real life cost accounting, and they proposed that students should also be given packages calculating these costs in addition to the cost accounting education presented in schools.

As one of the member of the accounting sector, do you think there should also be applied accounting courses besides the theoretical courses?

All the IAFAs unanimously answered this question as "yes, there should be". In addition to this question, they suggested

- That the faculties offering four year education set the last year as obligatory training and keep the track of it,

- That 45 days of training were not sufficient and efficient in vocational school of higher education,

- That accounting and finance faculties be established for those who would prefer accounting profession, and they pave the way for branching out in the profession.

Is the number of the accounting courses offered in educational institutions particularly business and accounting-finance departments enough?

The majority of the IAFAs stated that the number of the courses was sufficient but the course contents and the hours compared to its number were not enough. In addition, they suggested that applied courses should also be offered besides the theoretical courses.

On what level is the accounting education offered in Turkey in terms of catching up the international standards in accounting sector?

The vast majority of IAFAs expressed that Turkey was not behind the international standards, and they made various and interesting comments. Turkish government forced the companies, whose scales were determined within the scope of the new Turkish Code of Commerce (TCC) on July 1st, 2012, to apply the Turkish Financial Reporting Standards (TFRS) in accordance with the 
International Financial Reporting Standards (IFRS), which was published by Turkish Committee of Accounting Standards in accounting and financial reporting.

While IAFAs complained about the fact that the standards of Turkey which was accommodated in accordance with the International Standards were not fully applied and they changed too rapidly, they, in order to catch up the standards, suggested that the informal work be avoided, and that the controls in this regard be increased.

What is your opinion about the following question? Is it more appropriate to receive an accounting education in university years or start working directly in accounting sector in order to be more effective in accounting profession?

The majority of the IAFAs responded that the people who would go into that profession should first be educated and then dive into the sector, and they reemphasized the fact that the education should include application and training.

What are your personal views and suggestions for being more effective in accounting education in Turkey?

The common views and suggestions of the IAFAs as an answer to that question are as follows:

Education system based on rote learning should leave its place to applied education system.

In order to catch up the international standards in Turkey, the general accounting courses should obligatorily be given to the entrepreneurs before they get into the business just like the case in countries such as Germany and England.

The young people who will carry out the profession should learn a foreign language.

The costs are readily calculated by the packages installed on computers. These packages should be taught to the students.

\section{Result and Suggestions}

In this study, in addition to the fact that various comments have been revealed from the results obtained from the face to face interview method, the IAFAs in the most general sense emphasized the fact that the people who would choose the accounting profession should receive a good accounting education eluded from rotelearning.

All the IAFAs who were interviewed stated that the accounting education should be supported by application, practice and at least one year of training in addition to theory. The most important result from the face to face interviews is that the bond between the accounting education and the sector is composed of the

298 | Celal Bayar Üniversitesi Sosyal Bilimler Dergisi - Cilt: 13, Sayı: 2, Haziran 2015 
application, practice and training during the education. As a result of the interviews, we can state that the accounting education in our country does not correspond to real life accounting sector. Regarding this, IAFAs anticipated that the accounting and finance faculties should be established just like a medical, education or engineering faculties. They have the common view that just as the applications are carried out in the laboratories of these faculties, so can the similar practices and applications be carried out in the accounting and finance faculties.

Another topic that the IAFAs underlined is that due to the fact that the taxpayers ignore accounting, and want to pay less tax, which IAFAs found unethical, the necessity of informing the taxpayers is of vital importance. It is obvious that in order to carry out a more decent accounting profession, the fact that the firms should pay more attention to institutionalization will contribute to both the professional works of the firms and the economies of the country.

In the interviews, it has been found out that there is a difference between the theoretical knowledge offered in educational institutions and sector applications in terms of accounting. In addition, as a result of the interviews, it has been anticipated that both the laws to be forced and the universities offering accounting education should fulfill specific responsibilities in order to obtain success in accounting profession. That is, as a result, in order to apply accounting profession in a successful way, ones who will choose this path of profession should carry out their profession fondly just like the case in other professions. In order to carry out the accounting profession fondly, it is of vital significance that the codes should be forced which are suitable for the content of the profession, and that the members of the profession should be saved from the redundant workloads so as to make the profession professional. In addition, universities have many significant responsibilities in carrying out the profession in a successful way. The greatest responsibility of the universities is that they should provide students training opportunities by means of uninterrupted communication with the sectors towards which the students receive their education. As for the accounting sector, which is the basic topic of the study, it bears great significance that universities should be in constant cooperation with both the Department of Finance and profession chambers of accounting in making accounting profession appropriate for the Europe and World standards. 


\section{REFERENCES}

CHIA, Yew Ming (1995), "Decentralization, Management Accounting System (MAS), Information Characteristics and their Interaction Effects on Managerial Performance: A Singapore Study", Journal of Business Finance and Accounting, vol:22, no: 6, September, pp: 811-830.

ÇÜRÜK, Turgut ve DOĞAN, Zeki (2002), "Muhasebe Ders ve İçeriklerinin Verilme Düzeyleri Konusunda İşletmelerin Üniversitelerden Taleplerinin Tespitine İlișkin Bir Araștırma", Dokuz Eylül Üniversitesi I.I.I.B.F. Dergisi, sayı:1, cilt:17, ss.107-126.

DiNÇ, Engin ve KAYA, Uğur (2006), "Muhasebe Meslek Mensuplarının Meslek Ahlakı Kuralları Açısından Hizmet Satın Alanlar Tarafından Algılanma Biçimi Üzerine Bir Araștırma", Muhasebe ve Denetime Bakış Dergisi, sayı:17, cilt:5, ss.139-152.

DURAK, Gökhan (2009), Üniversitelerde Verilen Muhasebe Eğitiminin Kırklareli Yöresi'nde Faaliyet Gösteren Küçük Ve Orta Büyüklükteki İșletmelerin Beklentilerini Karşılama Düzeyinin Incelenmesi, Trakya Üniversitesi Sosyal Bilimler Enstitüsü, Yayınlanmamıș Doktora Tezi, Edirne.

DURSUN, Âdem (2006), Muhasebe Eğitiminde Kalite Arayışı, Seçkin Yayıncllık, Ankara.

HANSEN, Don, MOWEN, Maryanne ve GUAN Liming (2007),

"Cost Management, Accounting and Control", South-Western Learning, Mason.

HYVÖNEN, Timo (2003), "Management Accounting and Information Systems: ERP Versüs BoB", Europen Accounting Review, vol:12, no:1, pp:155-173.

KARAPINAR, Aydın (2001), "Avrupa Topluluğu Ülkelerinde Muhasebe Eğitimi ve Ülkemiz Muhasebe Eğitimi ile Karşılaştırılması", XX. Türkiye Muhasebe Eğitimi Sempozyumu, 23-27 Mayıs, Antalya, ss. 211-231.

MURTHY, Uday S. ve WIGGINS, Casper E. (1999), "A Perspective on Accounting Information Systems Research", Journal of Information Systems, vol:13, no:1, pp.3-6.

OKAY, Suat (2011), Muhasebe Hata ve Hilelerinin Meslek Etiği Açısından İrdelenmesi, Karamanoğlu Mehmetbey Üniversitesi, Sosyal Bilimler Enstitüsü, Yayınlanmamış Yüksek Lisans Tezi, Karaman.

PAKSOY, H. Mustafa, AKBULUT, Ramazan ve AYDIN, Vehbi. (2005), "Meslek Yüksek Okullarında Muhasebe Eğitiminin Yeterliliğinin Harran Üniversitesi Özelinde İncelenmesi ve Geleceğe İlişkin Bir Değerlendirme", Muhasebe ve Denetime Bakış Dergisi, sayı:15, cilt:5, ss.73-105. 
ŞENGEL, Salim (2011), "İşletmelerin Sosyal Sorumluluğu ve Bir Araştırma”, http://icongfesr2011.tolgaerdogan.net/documents/national_presantations/ul12.pdf (Erişim tarihi:25.12.2014).

YAYLA, Hilmi Erdoğan ve CENGiZ, Ekrem (2005), "Muhasebe Mesleğinin Tercih Edilmesinde Etkili Olan Faktörlerin Belirlenmesine Yönelik Bir Alan Çalışması: Karadeniz Teknik Üniversitesi Örneği", Muhasebe ve Denetime Bakış Dergisi, sayı:16, cilt:5, ss:147-168. 
